\title{
Retracted: Pharmacists in Critical Care
}

AK Mohiuddin, Assistant Professor

Department of Pharmacy, World University of Bangladesh, Bangladesh

This article has been retracted by the Editor and Publisher due to the inappropriate use of previously published work. This article has been retracted: please see INNOVATIONS in pharmacy retraction policy (https://pubs.lib.umn.edu/index.php/innovations/policies).

Corresponding author: AK Mohiuddin, Assistant Professor Department of Pharmacy, World University of Bangladesh 151/8, Green Road, Dhanmondi, Dhaka - 1205, Bangladesh Phone: +8801716477485; Email: trymohi@gmail.com 